\title{
Performance Analysis of Foreign Loans in Directorate General of Highways Ministry of Public Works
}

\author{
Yunik Eva Sarlina \\ Directorate of Program Development, Directorate General of Highways, Central Java, INDONESIA \\ lina_yunik@yahoo.co.id
}

\begin{abstract}
Provision of road infrastructure does, efficiently and effectively, have an effect on economy increase in a region. The limited ability of the government in the provision of funding for the road infrastructure requires the handling on the organizers of the roads, it also needs efforts to look for funding resources outside the APBN as a resource of funds for foreign loans. This study aims to know the process of foreign loans, the characteristics of each foreign loan, and the loan implementation performance in Directorate General of Highways, Ministry of Public Works. The research was using the qualitative descriptive methods focusing on thorough depiction of form, function, and meaning of prohibition; data collection was done by collecting the entire loan process from the preparation phase to the implementation phase through interviewing and documentation literature. The document consists of the loan agreement document, documents monthly reports and annual reports, lender regulations, legal regulations of the Republic of Indonesia, photo documentation and archives. The result showed that the scoring of performance, multilateral loan is better than bilateral loan. This is evidenced by higher score for multilateral loan than bilateral loan. Particularly in terms of regulations, multilateral loan having score 15, it was because the lender adjusts by existing regulations in Indonesia, while bilateral loan having score 13. Furthermore, from the aspect of financial benefits, bilateral loan have score of 41 and is more advantageous than the multilateral loan which score is 29.
\end{abstract}

Keywords: loan, lender, bilateral loan, multilateral loan

\section{INTRODUCTION}

Transportation is the veins on the politic life, economy, social culture, and national defense in which the role is very vital to the national security. The road infrastructure as part of the transportation system is regarded to create and increase the economic development. An adequate provision of the road infrastructure could affect the economy escalation of a region. In order to support the road handling, funding is needed from various resources, which includes loan and foreign grant, in addition from the traditional fund resource of The Indonesian Budget (APBN)/Regional Government Budget (APBD). In creating the cooperation with the lender, it needed the document on collaboration agreement or equated document. The deal on collaboration of Foreign Loan and Grant (Pinjaman dan Hibah Luar Negeri-PHLN) is a written agreement that arranges matters related to the foreign loan and grant, and the relation between the government and the lender.

\section{FOREIGN LOAN}

\subsection{Classification of Foreign Loan}

Sanuri (2005) stated that according to the fund resource, foreign loan types are as follows: a) Multilateral Loan, which is the loan that originated from international institutions, such as the World Bank and Asian Development Bank (ADB Annual Report, 2012)

b) Bilateral Loan, which is the loan that originated from member countries of CGI or directly from respective country (inter-government).

c) Syndicated Loan, which is the loan that originated from several banks and international nondepository institution. The lending is coordinated by one bank/non-depository institution that acts as the syndication lender.

According to the regulation, Sanuri (2005) classified the foreign loan into several types, i.e.:

a) Soft Loan (Concessional Loan), which is government foreign loan in order to fund the development projects. Concessional Loan could also be defined as loan that originated from the Official Development Assistance (ODA), either in bilateral or multilateral.

b) The semi-concessional loan, which is the loan with utilization that is almost equal to the soft loan, but with requirement that is heavier than soft loan, yet lighter than commercial loan. 


\section{FOREIGN LOAN AGREEMENT PROCESS AND MANAGEMENT}

Foreign Loan and Grant Agreement (Pinjaman dan Hibah Luar Negeri-PHLN) are an agreement held between the Indonesian Government and a country or creditor institution that provide loan, either cash loan, project loan or grant to the Indonesian government. The normal procedure in constructing the PHLN agreement is basically through negotiation, agreement signing, and ratification - or in this case, legal opinion which is published by the Ministry of Justice and Human Rights. Negotiation is held to discuss and to solve various issues that needed to be agreed upon and fulfilled both by the Indonesian Government and the creditor. Therefore, after the agreement is signed, the funded activity could work well and according to the agreed schedule. After the parties are agreed, the signing and the ratification of the agreement would follow. Foreign loan management is consisted of three stages (Sarlina, 2014), as follows:

a) Stage I is the foreign loan preparation or necessity identification step

b) Stage II is the foreign loan implementation step

c) Stage III is the foreign loan repayment and evaluation step

\section{RESEARCH METHODOLOGY}

\subsection{Data Collecting}

The research used the qualitative descriptive method with resources from secondary data. The data used were agreement documents, monthly and yearly report, Indonesian Republic legislation regulations, lender's regulation, photographs, and archives. The data needed to be was obtained from Foreign Cooperation and Financing Sub Directorate, Directorate General of Highways, Ministry of Public Work, and websites of government or lending institutions.

\section{RESEARCH RESULT AND DISCUSSION}

\subsection{Foreign Loan Management Scheme}

On the process of foreign loan management, the related institutions are Ministry of Finance, Ministry of Public Work, and National Development Planning Agency (Bappenas). The three institutions composed a list of project/program proposal that could be funded by the lender. Bappenas was being positioned as the interface between the government and the lender. Furthermore, the cycle and the process of Foreign Loan and Grant Agreement (Pinjaman dan Hibah
Luar Negeri-PHLN) according to the Foreign Cooperation Procedure are as seen in Figure 1.

From the general analysis result, the procedure in foreign loan management (Pinjaman Luar Negeri$P L N$ ) and foreign grant (Hibah Luar Negeri-HLN) are as follows:

a) Stipulation of foreign loan and grant proposal;

b) Setup on foreign loan and grant;

c) Foreign loan and grant implementation;

d) Loan and grant activity monitoring.

5.2 Stipulation of foreign loan and grant proposal (Bappenas, 2010)

a) In the case of project loan proposal, the State Minister of National Development Planning/Chairperson of Bappenas coordinates with the Minister of Finance in order to compose the Yearly and Mid-term Loan Utilization Plan which then is included in the Foreign Loan Utilization Plan (Rencana Pemanfaatan Pinjaman Luar Negeri-RPPLN).

b) Ministry of Public Works could submit proposal that to be funded from the foreign loan, to the Ministry of National Development Planning/National Development Planning Agency.

c) The stipulation on foreign loan and grant proposal is started by framing the policy and strategy of the foreign loan and grant necessity plan, as according to the Ministry of Public Works strategy plan.

d) Framing the policy and strategy is needed to set the criteria for the foreign loan and grant activities proposal in the Ministry of Public Works

e) Stipulation for the foreign loan and grant proposal is assigned in every five years.

f) Stipulation for foreign loan and grant proposal could be renewed and refined in every year according to the national development priority and necessity.

g) The Minister assigns policy, strategy, and criteria for foreign loan and grants necessity plan for the public works facilities and infrastructure, in which originated from the local government or The Base Administrative Unit (Satuan Administrasi Pangkal).

h) The criteria for foreign loan and grant plan assignment include the aspect of administration, technical, and financing. Administration aspect refers to the rating on the document and administration comprehensiveness. Technical includes the suitability on project proposal with the Strategic Plan (Renstra) or the mid-term development plan (Rencana Pembangunan Jangka Menengah), economic appropriateness, and 
financial appropriateness, loan continuation to the local government, managing capabilities of the executing institution, national and international issues. Financing includes congeniality with the foreign loan work plan (Rencana Kerja Pinjaman Luar Negeri-RKPLN), project distribution in between regions that funded from the foreign loan and grant, linkages with other project from the proposing local government/base administrative unit, congeniality with other project that directly linked with other institutions, implementation performance of the ongoing foreign loan and grant activity on the proposing local government, and the ability of providing matching grant.

i) Minister will coordinate with the related base administrative unit or local government.

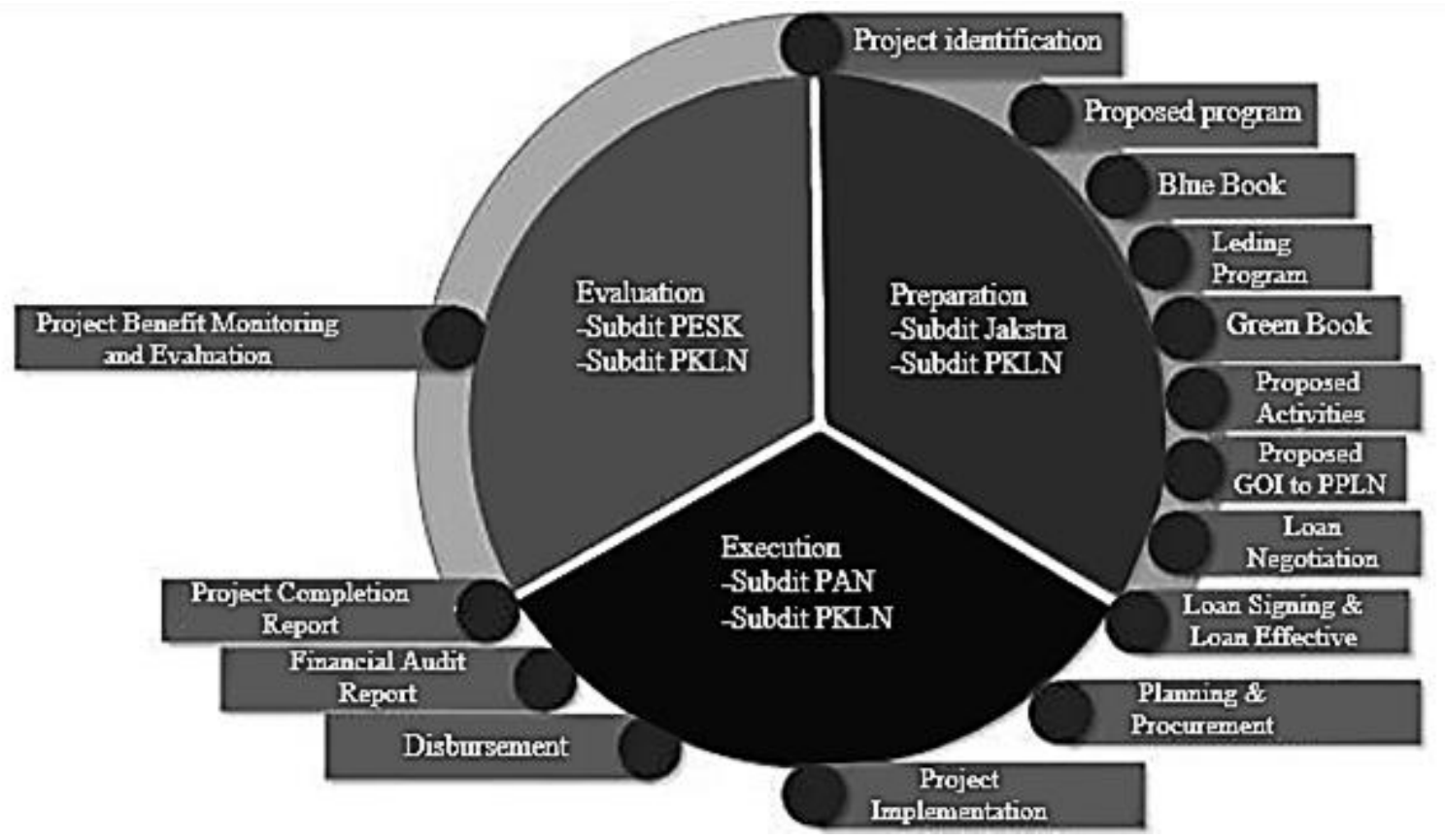

Figure 1. Foreign loan and grant process cycle. (Bappenas, 2006)

\subsection{Foreign Loan and Grant Setup}

Setup of the foreign loan is through the steps as follows (Bappenas, 2006):

a) Framing on the project plan detail. The proposed cooperation could be the leader's policy/directives, joint initiative, or response to offer given by donor country, for the further suggestion to the National Road Construction Agency (Balai Besar Pelaksanaan Jalan Nasional-BBPJN/Balai Pelaksanaan Jalan Nasional-BPJN) in the Directorate General of Highways. National Road Construction Agency then arranges the Terms of Reference related to these suggestions to be continued to the Sub-directorate of Strategy and Policy of Directorate of Planning, and for further adaption to the Mid-term Development Plan (RPJM).

b) Project implementation preparation.

c) Sub-directorate of Strategy and Policy present the cooperation proposal in the form of cooperation long list or foreign loan and grant plan list (Daftar Rencana Pinjaman dan Hibah Luar NegeriDRPHLN) to the Foreign Cooperation Bureau, in order to be evaluated in concern of the foreign loan utilization plan (Rencana Pemanfaatan Pinjaman Luar Negeri-RPPLN), and adjusted with the overall plan of the Ministry of Public Works.

d) Foreign Cooperation Bureau, Directorate General of the Ministry of Public Works proposing long list (resulted from Project Digest, Project Brief Information Sheet/PBIS, Project Proposal, Feasibility Study/FS result) to National Development Planning Agency.

Preparation of the foreign loan negotiation is through several steps, which are:

a) Bappenas conduct rating process to the proposed long list in order to gain a short list, by composing Mid-term Development Plan List (Daftar Rencana Pinjaman Luar Negeri Jangka MenengahDRPLNJM) or Blue Book.

b) The suggested short list further then be delivered to the proposing unit (Ministry of Public Works)

c) Identified projects with implemented preparation could be included to Lending Program or Pipeline Projects, which is still in the form of indicative list 
that would obtain mid-term loan financing from donor institution.

d) When it is considered being proper enough, the project then would be included in the Foreign Loan Priority Plan List (Daftar Rencana Prioritas Pinjaman Luar Negeri-DRPPLN) or Green Book.

e) The accepted proposal (short list) in the Bappenas would be forwarded its filing process by arranging application form. The Ministry of Public Works through the Foreign Cooperation Bureau then would forward the application form to Bappenas in order to be approved.

f) The proposal then to be forwarded to the intended foreign loan provider country (Negara Pemberi Pinjaman Luar Negeri-NPPLN)

g) The foreign loan provider country then conduct fact finding mission in order to assess the feasibility of the project which Indonesian Government has proposed. The result of the fact finding mission is the funding commitment to fund the proposed project, and if needed, the possibility to provide grant in order to increase implementation preparation. The result of the fact finding mission is Aide Memoire or Minutes of Discussion (MOD).

h) For the projects that have gained funding indication from the foreign loan provider country, implementation preparation process (pre appraisal and appraisal mission) then be conducted. The result of this mission is Project Appraisal Document (PAD) or Project Administration Management (PAM).

i) Loan negotiation is conducted between the Indonesian Government and the foreign loan provider country.

j) The result of the negotiation is included in Foreign Loan Agreement (Perjanjian Pinjaman Luar Negeri) which signed by the Indonesian Government and the foreign loan provider. The foreign loan agreement is to be contained at least: amount, allotment, right and obligation, clause and requirements.

\subsubsection{Foreign Loan Implementation}

Cooperation administrative process is included in the Cooperation Document signed by both parties: Government of the Republic of Indonesia and the Donor Country Representative. The foreign loan implementation is started with the project implementation plan, implementation program/action plan, project procurement, project implementation, project disbursement, financial audit report, and project completion report.

\subsection{Foreign Loan Project Monitoring}

The monitoring and evaluation of the implementation of project funded by the foreign loan and grant including progress on procurement process of goods and services, realisation of the funds absorption, physical implementation achievement, payment process, encountered problem or obstacles, yearly monitoring and evaluation, project implementation impact, and a needed follow-up steps by referring to the foreign loan agreement script (Naskah Perjanjian Pinjaman Luar Negeri-NPPLN) and the foreign grant agreement script (Naskah Perjanjian Hibah Luar Negeri-NPHLN).

\subsection{Characteristics of the Lending Institution}

In order to understand the suitable project type with the loan provider donor, the analysis is needed on characteristics of each donor and project types in the Highway Agency scope. Characteristics of each loan could be seen in Table 1 .

\subsection{Regulation Compatibility Analysis}

Before analysis on the regulation compatibility is conducted, the sub-aspect that would be rated needed to be determined first. For in rating regulation compatibility aspect, the rated sub-aspect is the main difference of Presidential Regulation No. 54 Year 2010 with the guidelines of each lending institutions.

To be able to rate this sub-aspect, indicator used for each sub-aspect needed to be stated. This indicator would compare each sub-aspect, in order to find whether it already compatible with the valid regulations as the basis. In the quantitative rating, the score given is in 1 to 5 scales, whereas score of 1 is the worst and score of 5 is the best. The worst stated for the most unsuitable aspects with the regulation and not able to accommodate Presidential Regulation. While the best stated for the most suitable aspects with the regulation and be able to accommodate Presidential Regulation. After scoring the Accommodation to Presidential Regulation and Integration to Development Planning, then the total score of each aspect could be sum up to compare the performance of each kind of loans. The rating process is presented in form of rating matrix in Table 2. 
Table 1. Loan characteristic

\begin{tabular}{|c|c|c|c|c|c|c|}
\hline Loan & $\begin{array}{l}\text { Funding } \\
\text { orientation }\end{array}$ & $\begin{array}{l}\text { Funding amount and } \\
\text { loan burden }\end{array}$ & Requirement aspect & $\begin{array}{l}\text { Aspect of } \\
\text { transfer of } \\
\text { technology }\end{array}$ & $\begin{array}{l}\text { Special } \\
\text { aspect }\end{array}$ & $\begin{array}{l}\text { Aspect of related } \\
\text { legal order }\end{array}$ \\
\hline JICA & Sectoral & $\begin{array}{l}\text { Loan rates relatively } \\
\text { low }(0.6 \%)\end{array}$ & $\begin{array}{l}\text { Feasibility Study } \\
\text { (FS) of economic, } \\
\text { social, financial, } \\
\text { technical, and } \\
\text { environmental } \\
\text { feasibility }\end{array}$ & $\begin{array}{l}\text { Less because } \\
\text { of funding } \\
\text { pressure on } \\
\text { certain } \\
\text { project }\end{array}$ & $\begin{array}{l}\text { Oriented on } \\
\text { using } \\
\text { product/resou } \\
\text { rce from } \\
\text { donor } \\
\text { country }\end{array}$ & $\begin{array}{l}\text { Scheme was } \\
\text { suitable with } \\
\text { JICA regulations }\end{array}$ \\
\hline AusAID & $\begin{array}{l}\text { Project and } \\
\text { study }\end{array}$ & $\begin{array}{l}\text { a) Loan rates } \\
\text { relatively low } \\
\text { b) Additional } \\
\text { burden from } \\
\text { Technical } \\
\text { Assistance (TA) } \\
\text { process and long } \\
\text { process with } \\
\text { strict } \\
\text { requirements }\end{array}$ & $\begin{array}{l}\text { a) Environmental } \\
\text { study document } \\
\text { b) FS document } \\
\text { c) Supporting study } \\
\text { document }\end{array}$ & $\begin{array}{l}\text { Very good } \\
\text { because of } \\
\text { support from } \\
\text { TA }\end{array}$ & $\begin{array}{l}\text { Oriented on } \\
\text { gender and } \\
\text { social } \\
\text { impacts }\end{array}$ & $\begin{array}{l}\text { Scheme was } \\
\text { suitable with } \\
\text { AusAid } \\
\text { regulations, yet } \\
\text { still possible for } \\
\text { further } \\
\text { adjustment }\end{array}$ \\
\hline $\begin{array}{l}\text { World } \\
\text { Bank }\end{array}$ & $\begin{array}{l}\text { Sectoral or } \\
\text { integrated } \\
\text { project but } \\
\text { lead to } \\
\text { integrated } \\
\text { project }\end{array}$ & 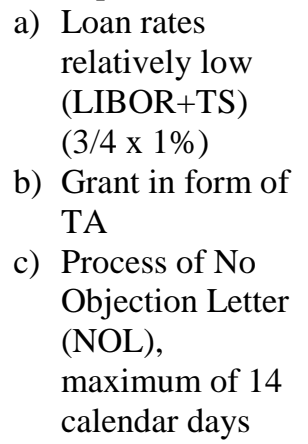 & $\begin{array}{l}\text { a) Poverty } \\
\text { reduction and } \\
\text { country } \\
\text { strategies } \\
\text { b) Project } \\
\text { information } \\
\text { c) Integrated } \\
\text { safeguard data } \\
\text { sheet }\end{array}$ & $\begin{array}{l}\text { Very good } \\
\text { because of } \\
\text { support from } \\
\text { TA }\end{array}$ & $\begin{array}{l}\text { Oriented on } \\
\text { environmenta } \\
1 \text { and social } \\
\text { impacts }\end{array}$ & $\begin{array}{l}\text { Scheme adjusted } \\
\text { with World Bank } \\
\text { regulations and } \\
\text { rules }\end{array}$ \\
\hline $\begin{array}{l}\text { Asian } \\
\text { Developm } \\
\text { ent Bank } \\
(\mathrm{ADB})\end{array}$ & $\begin{array}{l}\text { Sectoral or } \\
\text { integrated } \\
\text { project but } \\
\text { lead to } \\
\text { integrated } \\
\text { project }\end{array}$ & $\begin{array}{l}\text { Loan rates relatively } \\
\text { low (LIBOR+0.6\%) }\end{array}$ & $\begin{array}{l}\text { a) Design and } \\
\text { monitoring } \\
\text { b) Initial Poverty and } \\
\text { Social Assessment } \\
\text { c) Environmental } \\
\text { Assessment } \\
\text { Report } \\
\text { d) Resettlement } \\
\text { Planning } \\
\text { Document } \\
\text { e) Indigenous people } \\
\text { planning } \\
\text { document } \\
\text { f) Consultant Report }\end{array}$ & $\begin{array}{l}\text { Less because } \\
\text { of funding } \\
\text { pressure on } \\
\text { impacts }\end{array}$ & $\begin{array}{l}\text { Oriented on } \\
\text { environmenta } \\
1 \text { and social } \\
\text { impacts }\end{array}$ & $\begin{array}{l}\text { Scheme was } \\
\text { suitable with } \\
\text { ADB regulations }\end{array}$ \\
\hline
\end{tabular}


Table 2. Rating matrix of foreign loan provider institutions

\begin{tabular}{|c|c|c|c|c|c|c|}
\hline \multirow{3}{*}{ No. } & \multirow{3}{*}{ Loan } & \multicolumn{4}{|c|}{ Regulation Suitability Aspect } & \multirow{3}{*}{$\begin{array}{l}\text { Total } \\
\text { Score }\end{array}$} \\
\hline & & \multicolumn{2}{|c|}{$\begin{array}{l}\text { Accommodation to Presidential } \\
\text { Regulation }\end{array}$} & \multicolumn{2}{|l|}{ Integration to Development Planning } & \\
\hline & & Description & Score & Description & Score & \\
\hline 1 & $\begin{array}{l}\text { JICA, TPARCP I, } \\
\text { IP-529 (Tanjung } \\
\text { Priok Access Road } \\
\text { Construction Project } \\
\text { I) }\end{array}$ & $\begin{array}{l}\text { Accommodation level } \\
\text { in good degree }\end{array}$ & 4 & $\begin{array}{l}\text { This project has a tendency to give } \\
\text { benefit on small scope area. In this case, } \\
\text { only in the surrounding of the } \\
\text { construction area, which is in Tanjung } \\
\text { Priok access corridor. }\end{array}$ & 1 & 5 \\
\hline 2 & $\begin{array}{l}\text { AusAID, EINRIP, } \\
\text { AIPRD - L002 } \\
\text { (Eastern Indonesia } \\
\text { National Road } \\
\text { Improvement } \\
\text { Project) }\end{array}$ & $\begin{array}{l}\text { Accommodation level } \\
\text { in fair degree }\end{array}$ & 3 & $\begin{array}{l}\text { This project was considering to integrate } \\
\text { into vast region, which includes Bali, } \\
\text { West Nusa Tenggara, East Nusa } \\
\text { Tenggara, West Kalimantan, South } \\
\text { Kalimantan, North Sulawesi, Central } \\
\text { Sulawesi, South Sulawesi, and Southeast } \\
\text { Sulawesi; therefore the benefit tends to be } \\
\text { more comprehensive. }\end{array}$ & 5 & 8 \\
\hline 3 & $\begin{array}{l}\text { World Bank, SRIP, } \\
4834 \text { - IND/7786 - } \\
\text { IND (Strategic } \\
\text { Roads Infrastructure } \\
\text { Project) }\end{array}$ & $\begin{array}{l}\text { Accommodation level } \\
\text { in fair degree }\end{array}$ & 3 & $\begin{array}{l}\text { Regional scope in this project was quite } \\
\text { extensive, which includes Jambi, South } \\
\text { Sumatera, Lampung, Banten, West Java, } \\
\text { Central Java, and East Java; therefore the } \\
\text { benefit for the society also would be } \\
\text { more comprehensive. }\end{array}$ & 5 & 8 \\
\hline 4 & $\begin{array}{l}\text { ADB, RRDP, } 2817 \\
\text { - INO (Regional } \\
\text { Roads Development } \\
\text { Project) }\end{array}$ & $\begin{array}{l}\text { Accommodation level } \\
\text { in fair degree }\end{array}$ & 3 & $\begin{array}{l}\text { Effort of the regional development } \\
\text { integration in this project was seen in } \\
\text { project area scope which includes West } \\
\text { Kalimantan, East Kalimantan, East Java, } \\
\text { and Central Java }\end{array}$ & 4 & 7 \\
\hline
\end{tabular}

\subsection{Process Performance Analysis}

Rating to each loan comes from different resources is conducted by rating three aspects, which are the loan implementation preparation, the loan-funded project implementation, evaluation, and monitoring.

To conduct performance analysis from these three processes, a performance indicator is then made, with its performance could be compared both between the plan and realization, also between each different loan resources. Each aforementioned step has different performance indicators, so strength and weakness of each loan resources could be inspected. The indicators are mentioned below :

a) Loan-implementation preparation aspect has the lowest score if it needs more than 3.3 years, while it will reach the highest score if the preparation only needs less than 2.5 years.

b) Loan-funded project implementation aspects will have 5 indicators to be measured: duration between loan agreement and effective date of loan; the additional time of closing date; duration between tender opening until loan agreement; changing of agreement duration; average duration between publishing 0 agreement until 0 disbursements. The longer it takes, the lower performance outcome score (1). The fast and effective one will give the highest point (5).

c) Evaluation and monitoring aspects will be done by the lender. If all purpose of project is achieved or even beyond the expectation then the higher satisfactory will be achieved then the score will perform higher (5) when the project did not achieve anything from the purpose then it will be stated unsatisfactory with the lowest score (1).

The rating process is presented in rating matrix in Table 3. To facilitate the rating, the performance indicator is given a 1 to 5 scale, whereas score 1 is the indicator with worst performance, and score 5 is one with the best performance. 
Table 3. Rating matrix of project performance

\begin{tabular}{|c|c|c|c|c|c|c|c|c|c|c|}
\hline \multirow[b]{2}{*}{ No } & \multirow[b]{2}{*}{ Loan } & \multicolumn{2}{|c|}{ Preparation Step } & \multicolumn{3}{|c|}{ Implementation Step } & \multicolumn{3}{|c|}{ Evaluation Step } & \multirow[b]{2}{*}{$\begin{array}{l}\text { Total } \\
\text { Score }\end{array}$} \\
\hline & & Description & Score & $\begin{array}{l}\text { Loan } \\
\text { Duration } \\
\text { Description }\end{array}$ & Score & $\begin{array}{l}\text { Project } \\
\text { Duration } \\
\text { Description }\end{array}$ & Score & Description & Score & \\
\hline 1 & $\begin{array}{l}\text { JICA, TPARCP I, } \\
\text { IP-529 (Tanjung } \\
\text { Priok Access } \\
\text { Road } \\
\text { Construction } \\
\text { Project I) }\end{array}$ & $\begin{array}{l}\text { Initial } \\
\text { process } \\
\text { from blue } \\
\text { book to the } \\
\text { loan } \\
\text { signing } \\
\text { took } 3.2 \\
\text { years }\end{array}$ & 2 & $\begin{array}{l}\text { Idle time } \\
\text { from loan } \\
\text { signing to } \\
\text { effective } \\
\text { loan was } \\
\text { long and } \\
\text { has } \\
\text { extended } \\
\text { time until } \\
35 \% \text { of the } \\
\text { plan. }\end{array}$ & 5 & $\begin{array}{l}\text { Auction } \\
\text { process } \\
\text { duration was } \\
\text { quite long and } \\
\text { contract } \\
\text { implementation } \\
\text { duration } \\
\text { suffered a lot } \\
\text { of time } \\
\text { extension. }\end{array}$ & 7.7 & $\begin{array}{l}\text { Project still } \\
\text { ongoing }\end{array}$ & - & 14.7 \\
\hline 2 & $\begin{array}{l}\text { AusAID, EINRIP, } \\
\text { AIPRD - L002 } \\
\text { (Eastern } \\
\text { Indonesia } \\
\text { National Road } \\
\text { Improvement } \\
\text { Project) }\end{array}$ & $\begin{array}{l}\text { Initial } \\
\text { process } \\
\text { from blue } \\
\text { book to the } \\
\text { loan } \\
\text { signing } \\
\text { took } 3.7 \\
\text { years }\end{array}$ & 1 & $\begin{array}{l}\text { Idle time } \\
\text { from loan } \\
\text { signing to } \\
\text { effective } \\
\text { loan was } \\
\text { long and } \\
\text { has } \\
\text { extended } \\
\text { time until } \\
>100 \% \text { of } \\
\text { the plan. }\end{array}$ & 4 & $\begin{array}{l}\text { Process } \\
\text { duration is }<1 \\
\text { year. A lot of } \\
\text { packages have } \\
\text { prolonged } \\
\text { implementation } \\
\text { with period }>2 \\
\text { years }\end{array}$ & 9.4 & $\begin{array}{l}\text { Project still } \\
\text { ongoing }\end{array}$ & - & 14.4 \\
\hline 3 & $\begin{array}{l}\text { World Bank, } \\
\text { SRIP, } 4834 \text { - } \\
\text { IND/7786 - } \\
\text { IND (Strategic } \\
\text { Roads } \\
\text { Infrastructure } \\
\text { Project) }\end{array}$ & $\begin{array}{l}\text { Initial } \\
\text { process } \\
\text { from blue } \\
\text { book to the } \\
\text { loan } \\
\text { signing } \\
\text { took } 3.7 \\
\text { years }\end{array}$ & 1 & $\begin{array}{l}\text { Idle time } \\
\text { from loan } \\
\text { signing to } \\
\text { effective } \\
\text { loan was< } \\
2 \text { months } \\
\text { and has } \\
\text { extended } \\
\text { time until } \\
48 \% \text { of the } \\
\text { plan. }\end{array}$ & 6 & $\begin{array}{l}\text { Auction } \\
\text { process } \\
\text { duration was } \\
\text { averagely less } \\
\text { than } 1 \text { year, } \\
\text { only a few of } \\
\text { the package } \\
\text { suffered from } \\
\text { project } \\
\text { implementation } \\
\text { overdue }\end{array}$ & 11 & $\begin{array}{l}\text { Project has } \\
\text { just got } \\
\text { closing } \\
\text { date, } \\
\text { therefore } \\
\text { no } \\
\text { evaluation } \\
\text { has yet to } \\
\text { be done }\end{array}$ & - & 18 \\
\hline 4 & $\begin{array}{l}\text { ADB, RRDP, } \\
2817 \text { - INO } \\
\text { (Regional Roads } \\
\text { Development } \\
\text { Project) }\end{array}$ & $\begin{array}{l}\text { Initial } \\
\text { process } \\
\text { from blue } \\
\text { book to the } \\
\text { loan } \\
\text { signing } \\
\text { took } 2.3 \\
\text { years }\end{array}$ & 5 & $\begin{array}{l}\text { Idle time } \\
\text { from loan } \\
\text { signing to } \\
\text { effective } \\
\text { loan was< } \\
2 \text { months; } \\
\text { there was } \\
\text { no time } \\
\text { extension } \\
\text { yet for the } \\
\text { project was } \\
\text { just started }\end{array}$ & 9 & $\begin{array}{l}\text { Auction } \\
\text { process } \\
\text { duration took } \\
\text { quite long } \\
\text { time, almost } 2 \\
\text { years. Package } \\
\text { has just begun, } \\
\text { therefore no } \\
\text { time extension } \\
\text { yet }\end{array}$ & 12.2 & $\begin{array}{l}\text { Project just } \\
\text { begin }\end{array}$ & - & 26.2 \\
\hline
\end{tabular}


Table 4. Fund sources rank based on financial aspect

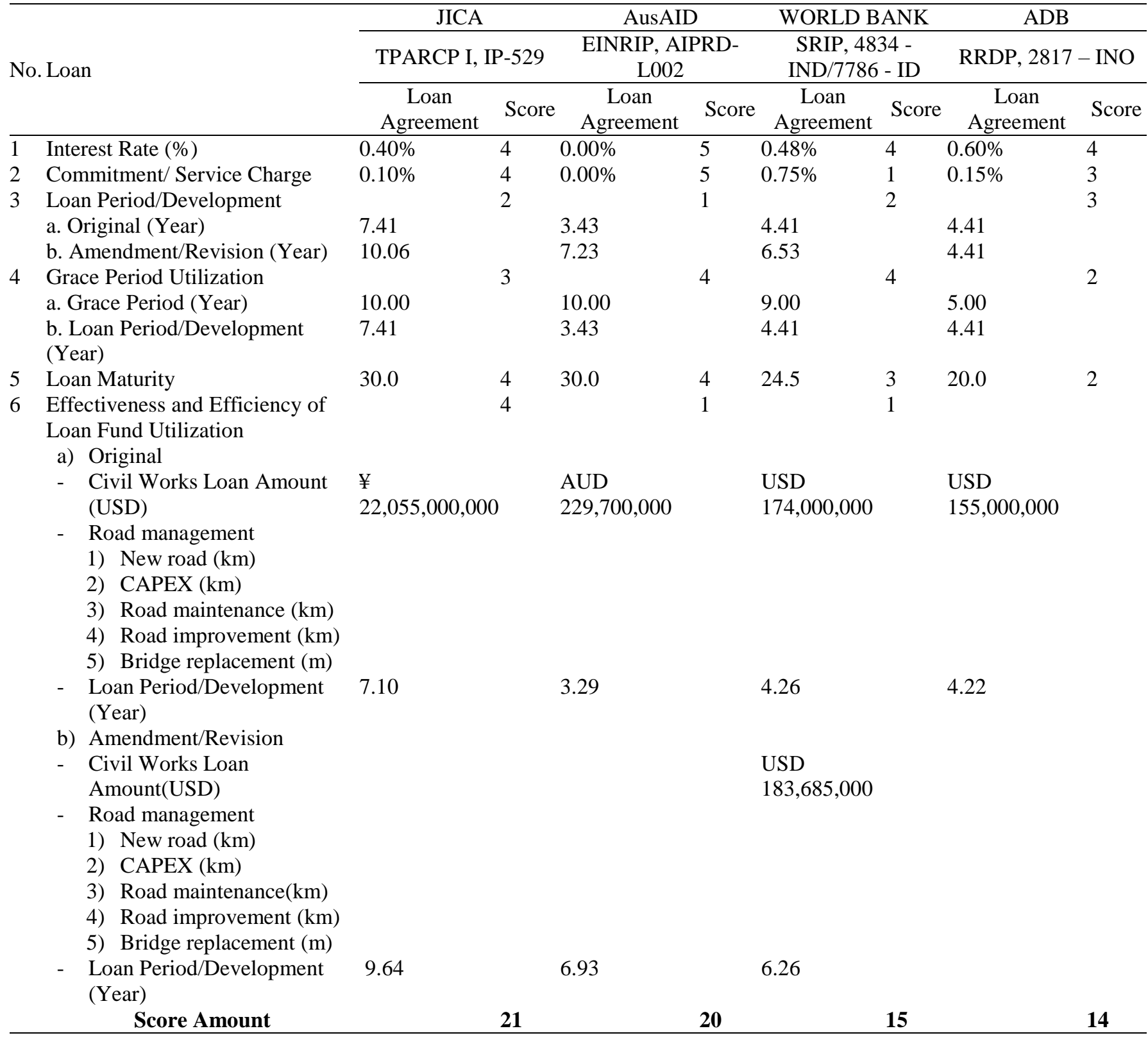

\subsection{Financial Analysis}

Financial aspect rating is score given for the rating criteria of interest rate, commitment fee, loan period, grace period, loan maturity, also effectiveness and efficiency of loan utilization. The rating uses score of $5,4,3,2$, and 1 . A score of 5 is the highest score for each rating criteria, whereas score of 1 is the lowest. The rating process is presented in Table 4 .

\subsection{Evaluation of Foreign Loan Performance}

To measure the performance of foreign loan implementation in Directorate General of Highways, comparison could be conducted on how far the time deviation in physical realization with the plan and or the requirements in the foreign loan documents and the supportive. The comparison could also be conducted between the fund absorption plans with the realization on the loan fund.

Realization of foreign loan fund absorption is based on withdrawal document or the Notice of Disbursement (NoD) received from four lenders, which is JICA, AusAID, World Bank, and ADB. This could be seen in Table 5. The implementation performance of the foreign loan in this report also measured by scale of the progress variant (PV). Calculation on each loan progress variant until 31 December 2013 is presented in Table 6 . 
Table 5. Data on foreign loan allocation and realization status of 31 December 2013

\begin{tabular}{|c|c|c|c|c|c|c|c|}
\hline \multirow{2}{*}{ No } & \multirow{2}{*}{$\begin{array}{l}\text { Project } \\
\text { Name/Loan }\end{array}$} & \multirow{2}{*}{ Loan Amount } & \multirow{2}{*}{$\begin{array}{l}\text { Contracted } \\
\text { Amount }\end{array}$} & \multicolumn{2}{|l|}{ Absorption } & \multirow{2}{*}{$\begin{array}{l}\text { Not Yet } \\
\text { Programmed }\end{array}$} & \multirow{2}{*}{$\begin{array}{l}\text { Remaining } \\
\text { Loan }\end{array}$} \\
\hline & & & & Total & $\%$ & & \\
\hline (a) & (b) & (c) & (d) & (e) & (f) & $(g=c-d)$ & $(\mathrm{h}=\mathrm{c}-\mathrm{e})$ \\
\hline 1 & JICA, IP-529 & $¥ 26,306,000,000$ & $18,804,176,834$ & $13,466,490,000$ & 51.19 & $7,501,823,166$ & $12,839,510,000$ \\
\hline 2 & AIPRD L002 & AUD $300,000,000$ & $263,489,183$ & $236,279,660$ & 78.76 & 36.510 .817 & $63,720,340$ \\
\hline 3 & $\begin{array}{l}\text { IBRD, 4834- } \\
\text { IND / 7786-ID }\end{array}$ & USD $181,455,176$ & $169,498,910$ & $162,930,617$ & 89.79 & $11,956,266$ & $18,524,559$ \\
\hline 4 & $\begin{array}{l}\text { ADB, } 2817 \text { - } \\
\text { INO }\end{array}$ & USD $180,0000,000$ & $8,038,405$ & $5,442,349$ & 3.02 & $171,961,595$ & $174,557,651$ \\
\hline
\end{tabular}

Table 6. Variant deviation of foreign loan status of December 2013

\begin{tabular}{|c|c|c|c|c|c|c|c|}
\hline \multirow{2}{*}{ No } & \multirow{2}{*}{$\begin{array}{l}\text { Donor/Loan } \\
\text { Number }\end{array}$} & \multirow{2}{*}{$\begin{array}{l}\text { Project } \\
\text { Name }\end{array}$} & \multirow{2}{*}{$\begin{array}{l}\text { Effective } \\
\text { Date }\end{array}$} & \multirow{2}{*}{ Closing Date } & \multirow{2}{*}{$\begin{array}{l}\text { Loan Period } \\
\text { (Month) }\end{array}$} & \multicolumn{2}{|c|}{ Progress Variant } \\
\hline & & & & & & $\%$ & Status \\
\hline 1 & JICA, IP-529 & IP-529 & 28 July 2005 & 28 January 2015 & 115.70 & 0.58 & Behind Schedule \\
\hline 2 & AIPRD L002 & EINRIP & $\begin{array}{l}\text { 4 March } \\
2008\end{array}$ & 31 December 2014 & 83.10 & 0.92 & Behind Schedule \\
\hline 3 & $\begin{array}{l}\text { IBRD, 4834- } \\
\text { IND/7786-ID }\end{array}$ & SRIP & $\begin{array}{l}1 \text { November } \\
2007\end{array}$ & 31 December 2013 & 75.07 & 0.90 & Behind Schedule \\
\hline 4 & $\mathrm{ADB}, 2817-\mathrm{INO}$ & RRDP & 3 July 2012 & 31 August 20016 & 50.67 & 0.06 & Behind Schedule \\
\hline
\end{tabular}

Table 7. Obstacle on Foreign Loan Project Status of 31 December 2013

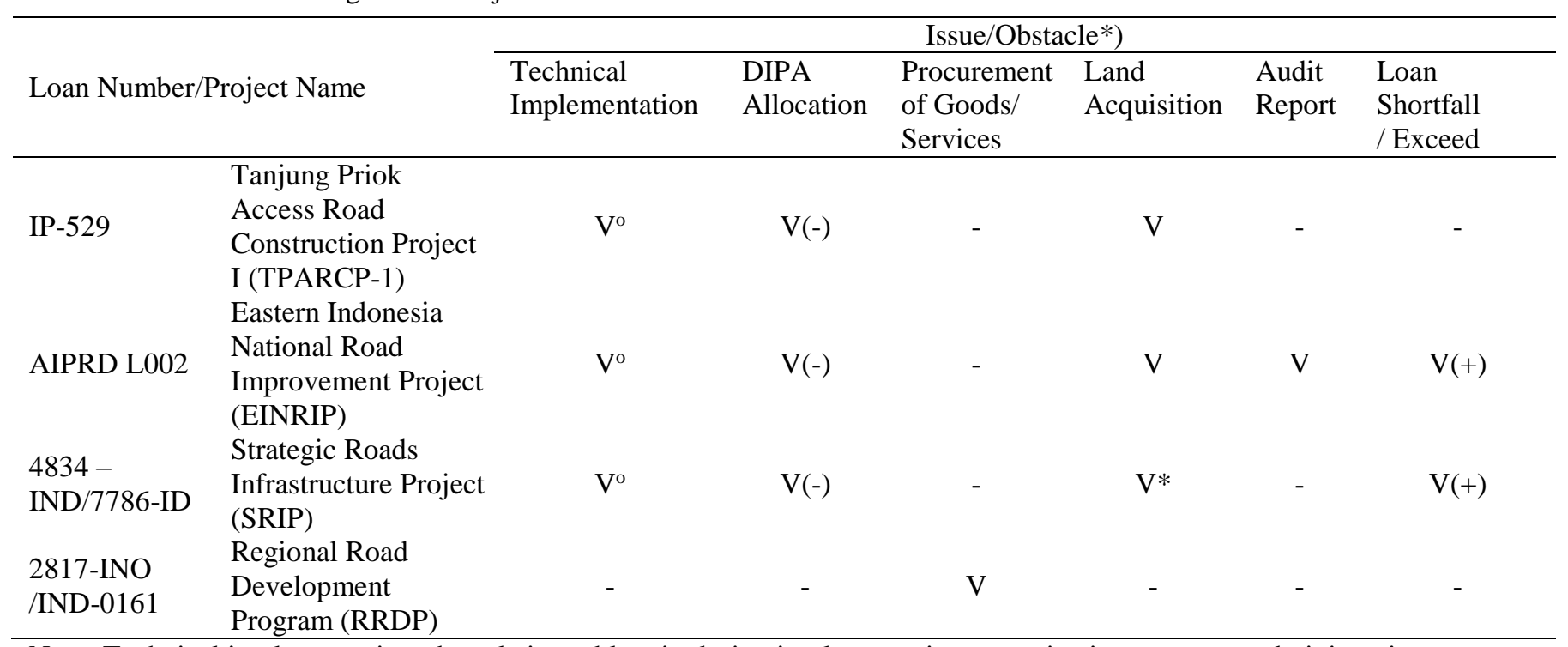

Note: Technical implementation obstacle is problem in design implementation, organization structure, administration, personnel or equipment mobilization, and coordination. DIPA Allocation obstacle is problem concerning of inclusion of loan fund allocation, matching grant, or administration requirement fulfillment.

Mark V: related problem exists; Mark V(-):lack of DIPA loan allocation; Mark V(+): there is remaining loan to be canceled; Mark V: problem on land title deed; Mark $\mathrm{V}^{\mathrm{o}}$ : potency of loan extension necessity

The result of analysis on projects that used foreign loan showed several typical obstacles as follows:

a) The technical problem in the field on EINRIP project and AIPRD L-002. There was a problem on cash flow of several projects, lack of manpower and material caused by the remote project location. On project IBRD SRIP, 4834-IND/7786-ID, there were a few problems, including the slow performance of the contractor, re-tendering on Bandar Lampung Bypass project. These issues caused delayed payment, and extension was needed on the loan validity period.

b) Non-technical issues. On JICA IP-529 project, there was problem arises on the land acquisition, as well as in the E-2 project package (Cilincing-Koja) so these caused delayed work and affected the loan extension probability. On project EINRIP, AIPRD L-002, there was problem on land acquisition, insufficient DIPA allocation, and on several projects, there was no follow-up on the audit finding of the BPKP team. On project $\mathrm{ADB}$ 
RRDP, 2817-INO, there was issue about time length of the procurement of goods and services. For more details, the matrix on the foreign loan implementation obstacles is presented in Table 7 .

\section{CONCLUSIONS AND SUGGESTIONS}

The organizing activities of Foreign Loan and Grant Agreement in the Ministry of Public Work starts from planning, purposes submission/stipulation, scoring and judgment, implementation, monitoring, and evaluation should be held based on existing government rule under Sub Directorate Ministry of Public Work c.q Overseas Cooperation Bureau.

Based on general analysis from the performance, the multilateral loan performs better than bilateral loan. Even though during the process, there are some cases showed that multilateral loan gives a bad performance due to its delays rate, but the benefit is good caused by the interest/importance of some sides is relatively not high. Particularly from the ruling side, multilateral loan gives a better performance due to the suitability rate between Central Government and lender government. The object is the lender that would adjust the rule based on the existing one in Indonesia.

From the performance process aspects, the multilateral loan also stated better than bilateral since the value of average ranking of development rate is higher. Though Asian Development Bank is a new starter loan, thus the scoring and judgment could not be done comprehensively. There is dynamic condition between cases of loan as follows:

a) Bilateral: The Government of Japan/JICA (Japan International Cooperation Agency) that has score of 21 with TPARCP I/ Tanjung Priok Access Road Construction Project I, Pemerintah Australia/AusAID (Australian Agency for International Development) with the EINRIP/Eastern Indonesia National Road Improvement Project, AIPRD - L002 that has score of 20. (AIPRD,2006)

b) Multilateral: World Bank with SRIP/Strategic Roads Infrastructure Project, 4834 - IND/7786 IND that has score of 15, and Asia Development Bank with RRDP/Regional Roads Development Project, ADB 2817 - INO that has score of 14.

Whole problems found in the foreign loan project that involved lender association and affecting the project performance could be identified as problems related to finance, problems related to procurement of goods and services, problems related to and acquisition. There should be an effort accomplished to solve the problems mentioned as follows:

a) The selection process of Framing on the project plan detail should prioritize the activity that has fulfilled the requirement and criteria of readiness.

b) Accelerate the completion of backlog problems, publishing the scope adjustment amendments and job volume due to escalation, exchange rate differences, and also half-funding of State Budget.

c) Accelerate the procurements of goods and services based on existing guidelines; routine meeting to discuss the problems and development rate of project with the related executors to solve the technical problems.

d) Coordination between land owner in the matter of forming the P2T (Land Aquisition Committee) Team will particularly responsible to accelerate land acquisition process, and states rules as part of criteria that will be used to accommodate the land certificate and/or real estate.

\section{REFERENCES}

Asian Development Bank, 2012a. Annual Report. [Online] Available at: http: //adb/org/sites/default/files/ar2012/oi-appendix1.pdf [Accessed 2 July 2013].

Asian Development Bank, 2012b. Funds. [Online] Available at: http://www.adb.org/site/funds/funds [Accessed 28 June 2013].

Bappenas, 2006. Petunjuk Teknis Pengajuan Usulan Kegiatan Yang Dibiayai Dari Pinjaman Dan/Atau Hibah Luar Negeri [Technical Reference of Proposal Program From Foreign Loan and Grant], Jakarta.

Bappenas, 2010. Petunjuk Pengusulan Kegiatan Yang Dibiayai Dari Pinjaman Dan/Atau Hibah Luar Negeri [Technical Reference of Proposal Program From Foreign Loan and Grant], Jakarta.

Sanuri, 2005. Pinjaman Luar Negeri Pemerintah (Loand Agreement Hingga Restrukturisasi) [Foreign Loan Agreement to Restructurization], Jakarta: Direktorat Luar Negeri Bagian Ekspor dan Impor Bank Indonesia.

Sarlina, Y. E., 2014. Analisis Kinerja Pelaksanaan Pinjaman Luar Negeri pada Bidang Kebinamargaan di Lingkungan Kementerian Pekerjaan Umum [Foreign Loan Performance Analysis in Directorate General of Highways] Yogyakarta: Master Thesis, Department of Civil and Environmental Engineering, Universitas Gadjah Mada. 